\title{
Familial Autism Genes
}

\author{
Ezgi Seda Yayla (1)
}

\section{THE CAUSES OF AUTISM ARE}

Although the etiology of autism is not known, firstly in 1943, American psychiatrist Leo Kanner defined Autism as language use disorders, inability to use the language of communication, excessive dependence, over-dependence against sameness, repetitive behaviors, life-long appearance as a chronic disorder, with changes in the appearance and severity of symptoms with age and maturation. ${ }^{[1]}$ He stated that no difference was observed between the social classes in terms of the risk of autism. ${ }^{[2]}$ According to the psychoanalytic approach, which is the popular trend of the period, by Kanner, it was defined only in relation to inadequate or incorrect parental attitudes, regardless of their biological basis. After Kanner's explanations, it has been revealed that as the researches on autism increase, autism may be due to biological reasons. Recent studies have focused on the genetic factors of the disease. The incidence of autism in the families and relatives of autistic children is more than $10-20 \%$ higher than the normal children, the rate of autism among siblings is $60-90 \%$, and the prevalence of one or more of the autism children in the family and relatives of autistic children. They are meaningful differences that can prove the findings that it is an inherited disease.

Department of Psychology, Demiroğlu Bilim University Medical School, Istanbul, Turkey

Correspondence: Ezgi Seda Yayla. Demiroğlu Bilim Üniversitesi Tıp Fakültesi, Psikoloji Bölümü, 34394 Şişli, İstanbul, Türkiye.

E-mail: ezgisedayayla@gmail.com

Cite this article as: Yayla ES. Familial Autism Genes. JEB Med Sci 2020;1(3):93-95.

doi: $10.5606 /$ jebms.2020.75621

Received : September 08, 2020

Accepted : October 13, 2020

Published online : December 19, 2020

(2020 Journal of Experimental and Basic Medical Sciences. All rights reserved.

\begin{abstract}
Autism is a common developmental disorder resulting from a lack or failure of different cognitive skills such as social interaction, communication and language disorders. In addition, stereotyped behaviors, limited activity and limited interests are observed in people with autism. An autistic person between 0-3 years shows these deficient, inadequate and different aspects. Autistic disorder is diagnosed according to DSM-IV criterias. The incidence is four times higher in boys than in girls. It is a lifelong disorder that cannot be cured completely. The incidence is around $1.7 \%$ in society. Although the etiology of autism is unknown, many studies have shown that genetic factor plays a major role. The rate of autism in the sibling of an individual with autism is between $10-20 \%$. This rate is well above the prevalence in society. Many studies conducted with the families of individuals with autism showed symptoms of autism characterized by problems in communication skills, introversion, language and speech problems in family members. In this review, familial autism genes will be discussed and the effects of heredity on autism will be discussed.

Keywords: Autism genes, autism spectrum disorders, autism, chromosomal abnormalities, etiology of autism, genetic transmission.
\end{abstract}

\section{BIOLOGICAL CAUSES}

In studies related to the causes of autism, it has been reported that exposure to thalidomide, especially valproic acid, anticonvulsants, some viral infections and various birth complications are associated with the development of autism. ${ }^{[3]}$ In addition, it is emphasized that the psychological stress factors encountered by the mother in the prenatal period are associated with the development of ASD. ${ }^{[4]}$ In imaging studies, some of the children with autism had features of macrocephaly, abnormal increase in cortical white matter, and abnormal growth characteristics in limbic structures such as frontal lobe, temporal lobe, amygdala. ${ }^{[5]}$ These structures are regions that have an important role in social relations, communication and motor skills that show deterioration in autism. ${ }^{[6]}$ 
In addition, in functional MR studies, hypoactivation $^{[7,8]}$ and impaired activity of mirror neurons were detected in the fusiform facial region in individuals with autism. ${ }^{[9]}$ However, none of these findings are specific for Autism Spectrum Disorder (ASD). ${ }^{[6]}$ The fact that autism can be seen with diseases of genetic origin, the high concordantity seen in monozygotic twins and the high risk of disease occuring in siblings reveal the importance of hereditary factors in the etiology of the disease. In twin studies, it has been reported that the concordant rates in single twin twins are between $60 \%$ and $90 \%$, while the concordant is between $0-10 \%$ in twin identical twins. ${ }^{[7]}$ Among siblings, it has been shown that $2-7 \%$ of co-diseases. ${ }^{[10]}$ In general, it is observed that genetic factors in autism are responsible for more than $90 \%$ of the occurrence of the disease. ${ }^{[11]}$

\section{GENES KNOWN TO BE ASSOCIATED WITH AUTISM}

Chromosome 2NRXN1, SCN7AChromosome 3GAT1, OXTR, CNTN3, SLC9A9, DIA1Chromosome 7FOXP2, WNT2, RELN, HOXA1, HOXB1, MET, EN2Chromosome 11HRASChromosome 15GABRB3, GABRA5, GABRG3, UBE3A, ATP10CChromosome 175-HTTChromosome 22SHANK3Chromosome XMeCP2, NLGN3, NLGN4, SLC9A6, FMR1.

Genetic research on autism; The first studies initiated to identify chromosomal regions and loci that may cause autism are in the form of connection and relationship studies. ${ }^{[12]}$

Although many genes and candidate genes related to autism were found, the major gene could not be detected. Significant results were obtained in 7 chromosome regions related to autism: $2,3,7,11$, $15,17, \mathrm{X}$ chromosomes. In addition, other candidate genes that are thought to cause autism are also being studied. The presence of many genes responsible for social interaction, language, communication and emotions indicates that there may be problems in more than one gene. With the development of technology, it will be possible to evaluate these genes and candidate genes together, and it will be possible to make more comments about the etiology of autism.

\section{SAMPLE CASE REPORT}

There are no case reports or studies regarding the risk of co-illness in separate triplets in autistic disorder and other ASDs. ${ }^{[13]}$ When studies conducted on twin twins are examined, it is seen that the fear of autism is between $0-10 \%$ in these cases. In siblings, the co-morbidity rates are between $2-7 \%$, similar to twins. ${ }^{[14]}$ Given the findings obtained from twins and siblings, the risk of co-illness among siblings is high compared to the general population, although all three siblings are unlikely to have coincidental illness. The occurrence of co-illness in our cases may have resulted from the fact that genetic factors and environmental factors are effective independently or by interacting with each other. Although no family history of common developmental disorders is described other than these cases, the co-illness observed in the presented cases may be related to the higher genetic susceptibility to autism in some families and the higher risk of spouse illness among siblings in these families. The fact that the presence of families with frequent autism spectrum disorders in family studies also supports this view. ${ }^{[15]}$ In addition, it was observed that non-autistic siblings had more functional losses such as language, communication, and learning disorders compared to the control group. ${ }^{[16]}$ It is claimed that genetic factors and family history are more effective in girls. In their study, Ritvo et al. Found 2 times more ASD in boys with ASD siblings than boys. Although ASD is seen four times more frequently in boys than in girls, it can be thought that two of our cases are gendermatched. ${ }^{[17]}$ Genetic diseases are detected in $10-15 \%$ of patients with ASD. The most commonly known are cytogenetic abnormalities such as fragile $\mathrm{X}(3 \%)$, tuberosclerosis (2\%), maternal duplication (2\%) of 15q1-q13 (16\%) deletion and duplication (1\%). ${ }^{[18]}$ But none of them are specific for ASD. Especially in the 2000 s, there was a change in the known genetic views about autism. Today, it is suggested that many genes, from which the common disease-common gene model is not correct for autism, are effective in the phenotype of the disease from mild to moderate level. ${ }^{[19]}$ In studies, the relationship between autism and the $9^{\text {th }}$ and $10^{\text {th }}$ regions of the street was found to be significant. ${ }^{[20]}$ Cadherin's neuronal activity is a known molecule. The presence of synaptic functions of the genes that cause fragile $X$ and Rett syndrome also led to the conversion of attention to synaptic dysfunction in terms of the etiology of ASD. Today, the most accepted model in autism development suggested by genetic and neurobiological evidence is that the model has a genetic-based synaptic maturation and connectivity problem. ${ }^{[6]}$

Despite all these developments, a single gene that could explain autism is not found yet, except for diseases that can be detected by some chromosomal 
and molecular tests. However, studies show that autism is the result of single nucleotide polymorphism, copy number difference, mutations in some target genes, epigenetic interactions (i.e. changes in the gene's nucleotide sequence that have changed function and changes that can be passed on to next generations by mitosis and/or meiosis) and environmental contribution. Each of these factors that mentioned contributes to the formation of autism, but we will be able to better understand the genetic mechanisms that lead to the autism picture through technological advances in gene analysis systems. ${ }^{[21]}$

As a result, autism is currently an incurable disease affecting the individual's social interaction, communication, language and intellectual skills based on his limited cognitive skills. Although the cause of the disease can not be explained for a single reason, the fact that it is seen significantly higher in siblings and especially in single twins reveals the effect of genetics related to chromosomal abnormalities. Genes that cause this disease that affect different cognitive skills continue to be explained with more meaningful data day by day with the recent studies and technological developments. In the light of these developments, the importance of genetic causes is emphasized for the differential diagnosis of the disease. This disease, which can not be treated today, will enable the development of methods to reduce symptoms after the biological factors become more evident with new developments.

\section{Declaration of conflicting interests}

The authors declared no conflicts of interest with respect to the authorship and/or publication of this article.

\section{Funding}

The authors received no financial support for the research and/or authorship of this article.

\section{REFERENCES}

1. Kanner L. Autistic disturbances of affective contact. Nervous Child 1943;2:217-50.

2. Baykara B. Otistik Çocukların Anne ve Baba-larında Geniş Otizm Fenotipinin Nörobilişsel Görünümünün Araştırılması. [Uzmanlık Tezi], İzmir: Dokuz Eylül Üniversitesi Tıp Fakültesi; 2003.

3. Nelson KB. Prenatal and perinatal factors in the etiology of autism. Pediatrics 1991;87:761-6.
4. Kinney DK, Munir KM, Crowley DJ, Miller AM. Prenatal stress and risk for autism. Neurosci Biobehav Rev 2008;32:1519-32.

5. Korvatska E, Van de Water J, Anders TF, Gershwin ME. Genetic and immunologic considerations in autism. Neurobiol Dis 2002;9:107-25.

6. Levy SE, Mandell DS, Schultz RT. Autism. Lancet 2009;374:1627-38.

7. Volkmar FR, Klin A. Kaplan \& Sadock's Comprehensive Textbook of Psychiatry. In: Kaplan HI, Sadock BJ, editors. Pervasive developmental disorders. 7th ed. New York: Springer; 2000. p. 2659-78.

8. Schultz RT. Developmental deficits in social perception in autism: the role of the amygdala and fusiform face area. Int J Dev Neurosci 2005;23:125-41.

9. Dapretto M, Davies MS, Pfeifer JH, Scott AA, Sigman M, Bookheimer SY, et al. Understanding emotions in others: mirror neuron dysfunction in children with autism spectrum disorders. Nat Neurosci 2006;9:28-30.

10. Volkmar FR, Pauls D. Autism. Lancet 2003;362:1133-41.

11. Rutter M. Genetic studies of autism: from the 1970 s into the millennium. J Abnorm Child Psychol 2000;28:3-14.

12. Korvatska E, Van de Water J, Anders TF, Gershwin ME. Genetic and immunologic considerations in autism. Neurobiol Dis 2002;9:107-25.

13. Available at: http://noropsikiyatriarsivi.com/sayilar/412/ buyuk/167-171.pdf

14. Volkmar FR, Pauls D. Autism. Lancet 2003;362:1133-41.

15. Sumi S, Taniai H, Miyachi T, Tanemura M. Sibling risk of pervasive developmental disorder estimated by means of an epidemiologic survey in Nagoya, Japan. J Hum Genet 2006;51:518-22.

16. Kaplan HI, Sadock BJ, editors. Pervasive Developmental Disorders. 8th ed. Philadelphia, PA: Lippincott Williams \& Wilkins; 2000.

17. Ritvo ER, Jorde LB, Mason-Brothers A, Freeman BJ, Pingree $C$, Jones $M B$, et al. The UCLA-University of Utah epidemiologic survey of autism: recurrence risk estimates and genetic counseling. Am J Psychiatry 1989;146:1032-6.

18. Kumar RA, Christian SL. Genetics of autism spectrum disorders. Curr Neurol Neurosci Rep 2009;9:188-97.

19. Cook EH Jr, Scherer SW. Copy-number variations associated with neuropsychiatric conditions. Nature 2008;455:919-23.

20. Wang K, Zhang H, Ma D, Bucan M, Glessner JT, Abrahams $\mathrm{BS}$, et al. Common genetic variants on 5 p14.1 associate with autism spectrum disorders. Nature 2009;459:52833.

21. Available at: https://www.otizmvakfi.org.tr/wp-content/ uploads/2018/01/otizm-ve-genetik_2013.pdf 